\title{
Studies on Effect of Coconut based Cropping System on the Yield and Soil Microbial Activity
}

\author{
Radhajogita Mondal*, A. C. Das and A. Bandyapadhyay \\ Department of Spices and Plantation Crops, Bidhan Chandra Krishi Viswavidyalaya, \\ Mohanpur, Nadia, West Bengal, 741252, India \\ *Corresponding author
}

\section{A B S T R A C T}

\section{Keywords}

Coconut, intercrop, yield, fungi, actinomycetes, bacteria, NPK and rhizosphere

\section{Article Info}

\section{Accepted:}

12 April 2021

Available Online:

10 May 2021
The coconut palm (Cocos nucifera linn.) is the most useful palm (every part) in the world. Hence, the coconut palm is called as tree of life and tree of heaven. Coconut palms are grown in more than 90 countries of the world. India ranks 3rd with respect to its production followed by Indonesia and Philippines. Main Coconut Producing States of India are Tamil Nadu, Karnataka, Kerala, Andhra Pradesh, Odisha and West Bengal etc. The present investigation was undertaken in the coconut experimental plot where tuberose, gerbera and marigold were grown as intercrop and observations were taken during flowering season of different plants in the HRS, Mandouri, BCKV on the year 2015-16. Regarding coconut yield in treatments, maximum average nut yield of coconut was recorded in T3 treatment. Maximum population of fungi was recorded under T2 treatment, population of actinomycetes was maximum under $\mathrm{T} 1$ and maximum population of bacteria was recorded under T1. With the respect of NPK content of soil, T3 treatment giving better results. But the rhizosphere soil of T2 treatment shows maximum cfu count of actinomycetes and bacteria as compared to other treatments under above experiment.

\section{Introduction}

The coconut palm (Cocos nucifera linn.) is the most useful palm in the world. Every part of the tree is useful to human life. Hence, the coconut palm is endearingly called tree of life or 'kalpavriksha' meaning the tree of heaven. Coconut palms are grown in more than 90 countries of the world, with a total production of 62 million tonnes per year. It is a high value perennial oilseed crop grown in an area of 2.39 million ha with a production of 21,892 million nuts in India (Economic Review, 2012). India ranks $3^{\text {rd }}$ with respect to its production followed by Indonesia and Philippines. The area, production and productivity of Coconut in India was recorded as 1975.81 ('000 ha), 20439.60 (million nuts), 
10345 nuts/ha (Horticulture Division, Dept. of Agriculture \& Cooperation, Ministry of Agriculture, Govt. of India, 2014-15).

Main Coconut Producing States in India are Tamil Nadu, Karnataka, Kerala, Andhra Pradesh, Odisha and West Bengal etc.

The morphological features of the coconut canopy necessitate its planting at a wide spacing and planted in square system with 7.5 $\mathrm{x} 7.5 \mathrm{~m}$ spacing. It is an established fact that the active roots of an adult coconut palm are concentrated laterally within a radius of $2 \mathrm{~m}$ from the base and vertically between 0.3 to 1.2 $\mathrm{m}$ from the surface of soil. Thus, in a pure stand of coconuts only about $25 \%$ of the soil mass is actually utilized by the coconut. A proper utilization of the remaining $75 \%$ of coconut land could be achieved by the practice of intercropping or farm diversification. The unstable copra prices in the national and international markets, small and marginal land holdings, lack of value addition facilities etc. have aggravated the economic difficulties to many coconut farmers.

A high efficiency in the use of available soil moisture and nutrients can be achieved by growing intercrops outside $2 \mathrm{~m}$ radius around the base of the palm. Growing of intercrops in coconut lands produces more food and agricultural products and commodities, providing food security for the people in both the rural and urban areas. At the same time, the practice generates jobs and livelihood, likewise enhancing farm income and purchasing power, hence, alleviating poverty in farming communities. Coconut-based highdensity multispecies cropping systems (HDMSCS) involving many crops like banana, pineapple, clove, and pepper was also established. In our present experiment, floricultural crops (marigold, tuberose and gerbera) were intercropped in coconut based cropping system.
Adoption of coconut based intercropping or mixed cropping system is one of the ways to utilize the natural resources effectively. The potential for increasing the productivity per unit area of land, time and inputs through high-density multispecies cropping system is considerably higher in perennial crops (Bavappa and Jacob, 1982). Bavappa et al., (1986) reported the advantages in high density multispecies cropping system involving compatible crops in coconut, with the increase in yield of coconut by 176 percent and additional income. According to Maheswarappa et al., (2003), high density multispecies cropping system provided a stabilized income to coconut farmers even at times of low price of coconut. Intercropping banana, hybrid

The soil microbial biomass has been studied in several multi-storey cropping systems in different states. Coconut-cacao mixed cropping have shown greater microbiological activity than coconut monocropping system. Beneficial microorganisms are one of the most integral parts of soil system which maintain the soil health and quality to make it dynamic for nutrient turn over and sustainability of cropping systems (Mishra et al., 2011; Ahemad and Kibert, 2014). A wide range of microorganisms is involved in various biotic activities such as organic matter decomposition, nitrogen fixation, solubilisation of micro and macro nutrients, maintenance of soil structure, soil borne disease suppression, plant growth promotion, siderophore production and release of hormones (Mishra et al., 2008). Among them, plant growth promoting microorganism's viz. Azotobacter chroococcum, PSB, AM fungi and actinomycetes play vital role in agriculture by mediating plant growth by alteration of whole microbial community in rhizosphere niche through the production of various substances (Mishra et al., 2009). Effect of growing floricultural crops under 
coconut based cropping system on yield, nutrient uptake and soil microbiological studies is an important arena which influences a lot on that performance of main crop as well as soil health improvement.

Very minimum information is available on above mentioned studies under west Bengal condition. Keeping this in view the present investigation has been scheduled on the following objectives:-

Performance of floricultural crops as intercrop on productivity of coconut.

Performance of floricultural crops as intercrop on soil microbial population status under coconut based cropping system..

Performance of floriculture crops on soil nutrient status under coconut based cropping system.

\section{Materials and Methods}

Different experiments under prospect of coconut based multiple cropping system in alluvial plains of West Bengal were carried out in the plantation of All India Coordinated Research Project on Palms at the Horticulture Research Station, Mondouri, Bidhan Chandra Krishi Viswavidyalaya, Nadia, West Bengal during the year 2015-16.

The research station is located $23.35{ }^{0} \mathrm{~N}$ latitude and $89^{\circ} \mathrm{E}$ longitudes, having an altitude of 9.75 meters above the mean sea level. The coconut plantation was established at 1982 and about 34 years old.

The floricultural crops like marigold, tuberose, gerbera were planted in the interspaces and maintained with scheduled cultural and nutrient management practices. The soil of the experimental plot was gangetic alluvial, sandy loam in texture, well drained with medium fertility status and good drainage as well as water holding capacity.

\section{Plan of work}

\section{Experimental details}

The coconut palms were spaced at $7.5 \mathrm{~m} \mathrm{X} 7.5$ $\mathrm{m}$. The study was based on 4 coconut based cropping models i.e., i) coconut + marigold, ii) coconut + tuberose, iii) coconut + gerbera and iv) coconut monocropping.

\section{Nutrient management of palms}

All the palms under the experimental plots received uniform dose of organic manures and fertilizers. Palms were provided with $25 \mathrm{~kg}$ compost, $500 \mathrm{~g} \mathrm{~N}, 250 \mathrm{~g} \mathrm{P}_{2} \mathrm{O}_{5}$ and $750 \mathrm{~g} \mathrm{~K}_{2} \mathrm{O}$ per palm per year.

\section{After care and management}

The cultural operations like weeding, removal of leaves, cleaning of crown etc. were done periodically on need based basis.

The palms were irrigated at 15-20 days interval from October to May. Necessary plant protection measures were also taken against pests and diseases.

\section{Experiment - 1}

To study the effect of different cropping system on the yield of main crop of coconut.

Age of palm - 34 years

Planting distance of coconut $-7.5 \mathrm{~m} \mathrm{X} 7.5 \mathrm{~m}$

Planting distance of intercrops $-3.5 \mathrm{~m}$ X $3.5 \mathrm{~m}$

Number of treatments -4

Number of replications - 5 


\section{Treatment details}

$\mathrm{T} 1-$ coconut + marigold

$\mathrm{T} 2$ - coconut + tuberose

$\mathrm{T} 3-$ coconut + gerbera

$\mathrm{T} 4$ - coconut as monocrop

\section{Observations to be recorded}

Average yield of coconut (nuts /ha)

Yield of flower crops (numbers of sticks or $\mathrm{kg}$ / ha / year)

\section{Experiment - 2}

To study the effect of different cropping systems on soil nutrient characteristics of the coconut based cropping system experimental plots.

\section{Observations to be recorded:}

Soil analysis of N, P and $\mathrm{K}$ at initial stage of experimentation

Soil analysis of N, P and K after completion of the experiment

\section{Experiment - 3}

To study the effect of different cropping systems on microbial population status of different coconut based cropping system of experimental plots.

\section{Observations to be recorded}

Counting of colony forming unit of fungi (cfu x $10^{-4} / \mathrm{g}$ of soil)

Counting of colony forming unit of bacteria (cfu $\times 10^{-5} / \mathrm{g}$ of soil)

Counting of colony forming unit of actinomycetes (cfu x $10^{-5} / \mathrm{g}$ of soil)

\section{Experiment - 4}

Economic analysis of different coconut based cropping system.

\section{Observations to be recorded}

Yield parameter of intercrops and main crop

Number of nuts/palm/year

Number of nuts/ha/yr.

\section{Soil N, P and K Analysis}

The soil samples were collected from various crop plots in interspaces and coconut basin at $0-25 \mathrm{~cm}$ depth before initiation and after completion of the experiment.

Total nitrogen content of soil was determined in percentage in micro Kjeldahl method (Jackson, 1973). Available phosphorous content of soil was determined in Olsen method (Jackson, 1973).

Available potassium was determined by leaching the soil with neutral normal ammonium acetate and estimating potassium by Flame Photometer method (Murhr et al., Jackson, 1973).

\section{Procure of serial dilution and pour plate method}

The viable microbial population counts were analysed by the standard technique of serial dilution and pour plating method (Pramer \& Schmidt, 1965). Plates were incubated at $30^{\circ} \mathrm{C}$. The counts were taken at $4^{\text {th }}$ days of incubation. The results were reported as colony forming unit per $\mathrm{g}$ of soil. The procedures are given below

Soil sample collection, Apparatus cleaning and washing, Making of water blank, Media 
preparation, Sterilization, Serial dilution, Pour plating, Incubation and Colony counting.

\section{Benefit: cost ratio}

The benefit: cost ratio for the treatments was calculated on the basis of cost of cultivation, gross return and net return. The economic assessment was carried out considering the cost of inputs and market price of the produce during the period of experimentation. Comparative economics of different coconut based cropping systems were made. Different input and output parameters considered calculating benefit: cost ratios are given below:-

Yield of intercrop

Value of intercrop

Cost of cultivation of intercrop

Maintenance cost of main crop

Return from intercrop

Net return from system

The yield of coconut and yield of different flower intercrops were taken for the present investigation.

The nitrogen, phosphorus and potassium content of the monocrop and intercrops growing soils were studied at a depth of 0-25 $\mathrm{cm}$.

\section{Results and Discussion}

In the present investigation studies on the effect of different flowering crops under coconut based cropping system on yield, soil $\mathrm{N}, \mathrm{P}$ and $\mathrm{K}$ content and soil microbial population studies have been undertaken, the results of which are being presented below :-

\section{Effect of different flower based cropping system on yield of main crop coconut}

Data presented in table no.1, in terms of annual nut yield, highly significant difference was observed among plots with different flower intercrop combinations over the control.

Regarding coconut yield in treatments with different flowers, maximum average nut yield of coconut (16525 nut/ha/year) was recorded in T3 (coconut + gerbera) treatment followed by $\mathrm{T} 2$ (coconut + tuberose) treatment $(16503$ nut/ha). Minimum average nut yield of coconut (16350 nut/ha) was recorded in treatment $\mathrm{T} 1$ as compared to control respectively. Regarding the production of flowering intercrops, treatment T3 (coconut + gerbera) was recorded highest stick production (242371 sticks/ ha/ yr.) followed by T2 (coconut + tuberose) treatment (185000 sticks/ ha/yr.) respectively.

Data based on nut production in table no. 1, more nuts obtained significantly from treatment T3 (coconut + gerbera). Highly significant improvements in yield were noted on coconut as more intercrops were planted as compared to those palms without intercrops.

Data revealed from above table no.2, N, P and $\mathrm{K}$ content of soil in the interspaces was higher than initial condition.

Nitrogen, phosphorus and potassium contents were observed more in the rhizosphere soil of T3 (coconut + gerbera) treatment as compared to initial condition with respect to $\mathrm{T} 1, \mathrm{~T} 2$ and control treatments. But there was no significant difference between the potassium content in rhizosphere of $\mathrm{T} 1$ and $\mathrm{T} 3$ treatments.

Data revealed from table no.3, on microbial population per gram of soil (actual soil in 1 
gm soil without moisture) recorded maximum population of fungi $\left(21.4 \times 10^{4} \mathrm{cfu}\right)$ under T2 (coconut + tuberose) treatment followed by $\mathrm{T} 3$ (coconut + gerbera) and $\mathrm{T} 1$ (coconut + marigold) treatments with $20.4 \times 10^{4} \mathrm{cfu}$ and $7.1 \times 10^{4}$ cfu respectively as compared to control (coconut monocrop $=3 \times 10^{4} \mathrm{cfu}$ ). Data recorded in table no.3, on microbial population per gram of soil (actual soil in 1 gm soil without moisture) was maximum with respect to population of actinomycetes ( $89 \mathrm{x}$ $10^{5} \mathrm{cfu}$ ) under $\mathrm{T} 1$ (coconut + marigold) treatment followed by $\mathrm{T} 3$ (coconut + gerbera) and $\mathrm{T} 2$ (coconut + tuberose) treatments with $69 \times 10^{5}$ cfu and $64 \times 10^{5}$ cfu respectively as compared to control (coconut monocrop $=59$ x $\left.10^{5} \mathrm{cfu}\right)$.

Studies on microbial populations per gram of soil (actual soil in $1 \mathrm{gm}$ soil without moisture) under flower based cropping system recorded maximum population of bacteria $\left(76 \times 10^{5}\right.$ cfu) under $\mathrm{T} 1$ (coconut + marigold) treatment followed by $\mathrm{T} 2$ (coconut + tuberose) and $\mathrm{T} 3$ (coconut + gerbera) treatments with $72.5 \times 10^{5}$ cfu and $43 \times 10^{5}$ cfu respectively as compared to control (coconut monocrop $=37 \times 10^{5} \mathrm{cfu}$ ).

Experiment on microbial population per unit of soil, fungal population was minimum in $\mathrm{T} 1$ treatment as compared to treatments T2, T3 and control.

There was no minimum difference between $\mathrm{T} 2$ and T3 treatments as compared to T4 treatment. But actinomycetes cfu count was recorded reverse trend as compared to fungal cfu count.

Because, T1 treatment shows highest bacterial population as compared to T2, T3 and control. There was not much difference between T2 and T3 treatments as compared to control. In case of bacterial population, T3 shows minimum cfu count, but there was difference between $\mathrm{T} 1$ and $\mathrm{T} 2$ treatments as compared to control.

\section{Moisture content of soil}

Data revealed from table no.4, the moisture content of rhizosphere soil of $\mathrm{T} 2$ treatment was observed maximum $(17.97 \%)$ as compared to other treatments under the present experiment.

Data revealed from table no.5, on yield and economics of commercial flowering crops intercropped in coconut garden, treatment T3 (coconut + Gerbera) recorded highest $\mathrm{B}$ : C ratio (1.74) followed by treatments $\mathrm{T} 2$ (coconut + tuberose) andT1 (Coconut + Marigold) with 1.73 and $1.70 \mathrm{~B}$ : $\mathrm{C}$ ratio as compared to control respectively.

In the present study in coconut plantation, coconut recorded highest yield (16525 nut/ha/year) in treatment $\mathrm{T} 3$ (coconut + gerbera) followed by $\mathrm{T} 2$ (coconut + tuberose) treatment (16503 nut/ha) and among intercrops, gerbera plant giving higher production of sticks (242371 sticks/ ha/ yr.) followed by tuberose plant (185000 sticks/ ha /yr.) as compared to control respectively.

Investigation of flower based intercropping system in coconut plantation, on $\mathrm{N}, \mathrm{P}$ and $\mathrm{K}$ content of soil of $\mathrm{T} 3$ (coconut + gerbera) treatment possess higher $\mathrm{N}, \mathrm{P}$ and $\mathrm{K}$ content $(266.85,81.56$ and $285.57 \mathrm{~kg} / \mathrm{ha})$ as compared to initial condition with respect to $\mathrm{T} 1, \mathrm{~T} 2$ and control treatments.

In our present study in coconut field, fungi population was more in intercropping of tuberose treatment $\left(21.4 \times 10^{4} \mathrm{cfu} / \mathrm{g}\right)$ followed by gerbera treatment $\left(20.4 \times 10^{4} \mathrm{cfu} / \mathrm{g}\right)$ during flowering period. There was not much difference in the fungi population of $\mathrm{T} 2$ and T3 treatments. 
Table.1 Effect of different flower based cropping system on yield of main crop coconut and intercrop.

\begin{tabular}{|c|c|c|}
\hline Flower crops & $\begin{array}{c}\text { Yield of flower crops (sticks or } \\
\text { kg/ha/year) }\end{array}$ & $\begin{array}{c}\text { Average yield of coconut } \\
\text { (nut per ha) }\end{array}$ \\
\hline $\begin{array}{c}\text { coconut + marigold } \\
\text { (T1) }\end{array}$ & $11852(\mathrm{~kg})$ & 16350 \\
\hline $\begin{array}{c}\text { coconut + tuberose } \\
\text { (T2) }\end{array}$ & 185000 & 16503 \\
\hline $\begin{array}{c}\text { coconut + gerbera } \\
\text { (T3) }\end{array}$ & 242371 & 16525 \\
\hline $\begin{array}{c}\text { Coconut as monocrop } \\
\text { (T4) }\end{array}$ & - & 16317 \\
\hline
\end{tabular}

Table.2 Effect of different flower based cropping system on N, P and K content of soil.

\begin{tabular}{|c|c|c|c|c|c|}
\hline $\begin{array}{c}\text { Nutrients } \\
\text { (kg/ha) }\end{array}$ & Initial & $\begin{array}{c}\text { coconut + } \\
\text { marigold (T1) }\end{array}$ & $\begin{array}{c}\text { coconut + } \\
\text { tuberose (T2) }\end{array}$ & $\begin{array}{c}\text { coconut + } \\
\text { gerbera (T3) }\end{array}$ & $\begin{array}{c}\text { Coconut as } \\
\text { monocrop (T4) }\end{array}$ \\
\hline $\mathbf{N}$ & 252.56 & 263.85 & 266.47 & 266.85 & 262.58 \\
\hline $\mathbf{P}$ & 79.52 & 81.53 & 81.53 & 81.56 & 80.56 \\
\hline $\mathbf{K}$ & 281.53 & 285.57 & 283.56 & 285.57 & 282.73 \\
\hline
\end{tabular}

Table.3 Studies on proliferations of microorganisms in the rhizosphere soils of different flower based cropping system at their flowering stages

\begin{tabular}{|c|c|c|c|c|c|c|c|c|c|c|c|c|}
\hline \multirow{3}{*}{$\begin{array}{l}\text { Flowering } \\
\text { plants and } \\
\text { main crop }\end{array}$} & \multicolumn{12}{|c|}{ Population of microorganisms } \\
\hline & \multicolumn{4}{|c|}{$\begin{array}{c}\text { Fungi } \\
\text { (cfuX } 10^{4} \text { per g) }\end{array}$} & \multicolumn{4}{|c|}{$\begin{array}{l}\text { Actinomycetes } \\
\left(\mathrm{cfu} X 10^{5} \text { per g) }\right.\end{array}$} & \multicolumn{4}{|c|}{$\begin{array}{c}\text { Bacteria } \\
\left(\mathrm{cfuX} 10^{5} \text { per } \mathrm{g}\right)\end{array}$} \\
\hline & $\mathrm{R} 1$ & $\mathrm{R} 2$ & $\mathrm{R} 3$ & Mean & $\mathrm{R} 1$ & $\mathrm{R} 2$ & R3 & Mean & $\mathrm{R} 1$ & R2 & $\mathrm{R} 3$ & $\begin{array}{c}\text { Mea } \\
\mathrm{n}\end{array}$ \\
\hline $\begin{array}{l}\text { Coconut + } \\
\text { Marigold } \\
\quad \text { (T1) }\end{array}$ & 7 & 6.5 & 7.8 & 7.1 & 88 & 90 & 89 & 89 & 79 & 73.4 & 76 & 76 \\
\hline $\begin{array}{c}\text { Coconut + } \\
\text { Tuberose (T2) }\end{array}$ & $\begin{array}{c}21 . \\
4\end{array}$ & 21.4 & 21.4 & 21.4 & 68 & 64 & 60 & 64 & 56 & 72.5 & 89 & 72.5 \\
\hline $\begin{array}{l}\text { Coconut + } \\
\text { Gerbera } \\
\text { (T3) }\end{array}$ & 7 & 6.6 & 6.8 & 20.4 & 68 & 69 & 71 & 69 & 43 & 42 & 44.7 & 43 \\
\hline $\begin{array}{l}\text { Coconut } \\
\text { monocrop } \\
(\mathrm{T} 4)\end{array}$ & 2 & 5 & 3 & 3.3 & 51 & 46 & 45 & 47.3 & 28 & 32 & 34 & 31.3 \\
\hline
\end{tabular}


Table.4 Studies on moisture content of rhizosphere soil

\begin{tabular}{|c|c|c|c|c|c|c|}
\hline Treatment & $\begin{array}{c}\text { Weight } \\
\text { of box } \\
\text { (g) }\end{array}$ & $\begin{array}{c}\text { Weight of } \\
\text { box + wet } \\
\text { soil (g) }\end{array}$ & $\begin{array}{c}\text { Weight of } \\
\text { moist soil } \\
\text { (g) }\end{array}$ & $\begin{array}{c}\text { Weight of } \\
\text { box + dry } \\
\text { soil (g) }\end{array}$ & $\begin{array}{c}\text { Weight of } \\
\text { dry soil } \\
\text { (g) }\end{array}$ & $\begin{array}{c}\text { Moisture } \\
\text { content } \\
\text { (g) }\end{array}$ \\
\hline $\begin{array}{c}\text { coconut + } \\
\text { marigold } \\
\text { (T1) }\end{array}$ & 25.340 & 88.420 & 63.08 & 73.7 & 48.3 & 14.78 \\
\hline $\begin{array}{c}\text { coconut + } \\
\text { tuberose } \\
\text { (T2) }\end{array}$ & 23.600 & 96.370 & 72.77 & 78.4 & 54.8 & 17.97 \\
\hline $\begin{array}{c}\text { coconut + } \\
\text { gerbera (T3) }\end{array}$ & 24.720 & 93.040 & 68.32 & 76.9 & 52.18 & 16.14 \\
\hline $\begin{array}{c}\text { Coconut as } \\
\text { monocrop } \\
\text { (T4) }\end{array}$ & 25.553 & 92.61 & 68.05 & 76.4 & 51.76 & 16.29 \\
\hline
\end{tabular}

Table.5

+ Table no.10: Yield and economics of commercial flowering crops intercropped in coconut garden (Mondouri). B: C ratio was calculated on the basis of corresponding market rates. (2015-16)

\begin{tabular}{|c|c|c|c|c|c|c|c|}
\hline Crop & Stick Yield & $\begin{array}{c}\text { Nut } \\
\text { yield/ha }\end{array}$ & $\begin{array}{c}\text { Gross } \\
\text { return/ } \\
\text { ha (Rs) }\end{array}$ & $\begin{array}{c}\text { Expenditure } \\
\text { /ha (Rs) }\end{array}$ & $\begin{array}{c}\text { Net return/ha } \\
\text { (Rs) }\end{array}$ & B:C & Duration \\
\hline $\begin{array}{c}\text { Coconut } \\
+ \\
\text { Marigold }\end{array}$ & $11825 \mathrm{~kg}$ & 16350 & 423650 & 248008 & 175642 & 1.70 & $\begin{array}{c}\text { Dec- } \\
\text { February- } \\
16\end{array}$ \\
\hline $\begin{array}{c}\text { Coconut } \\
+ \text { Tube } \\
\text { Rose }\end{array}$ & 185000 & 16503 & 535030 & 309658 & 225372 & 1.73 & $\begin{array}{c}\text { June15- } \\
\text { November } \\
15\end{array}$ \\
\hline $\begin{array}{c}\text { Coconut } \\
+ \text { Gerbera }\end{array}$ & 242371 & 16525 & 468214 & 268408 & 199806 & 1.74 & $\begin{array}{c}\text { Nov15-Feb- } \\
16\end{array}$ \\
\hline $\begin{array}{c}\text { Mono } \\
\text { crop }\end{array}$ & - & 16317 & 163170 & 95908 & 67262 & 1.70 & $\begin{array}{c}\text { July14- } \\
\text { June15 }\end{array}$ \\
\hline
\end{tabular}

(Marigold@ Rs22/kg, Tuberose@Rs2/stick, Gerbera@Rs1.25/stick, Coconut @ Rs 10/piece) 
Fig.1 Average yield of coconut (nut per ha).

\section{YIELD OF COCONUT}

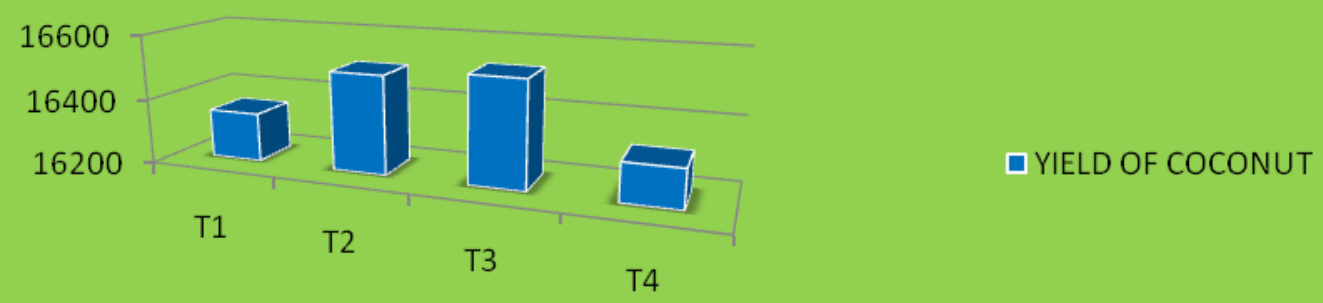

Fig.2 N, P and K content of soil ( $\mathrm{kg} / \mathrm{ha})$.

\section{$\mathrm{N}, \mathrm{P}$ and $\mathrm{K}$ content of soil}

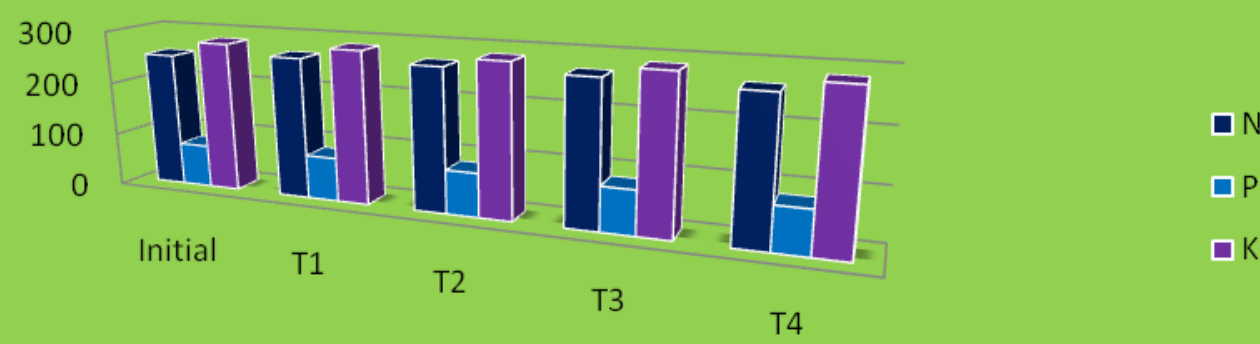

Fig.3 Counting of fungi population (cfuX10 4 per g).

\section{FUNGI CFU}

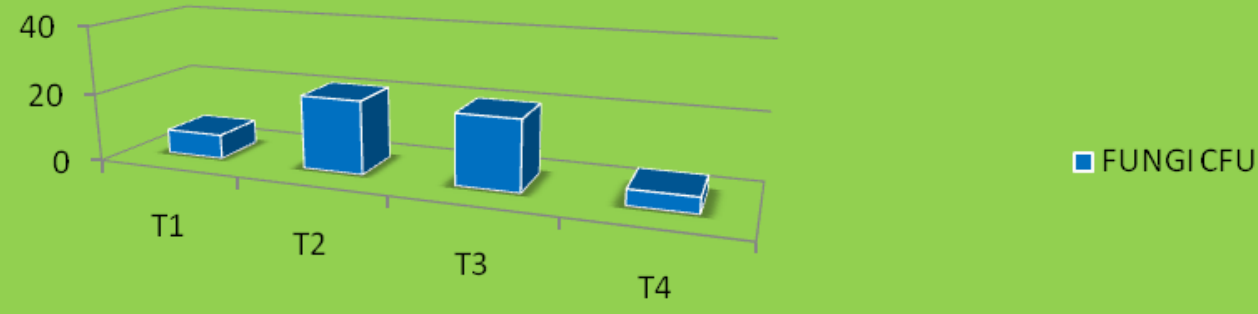


Fig.4 Counting of Actinomycetes population (cfuX10 5 per g).

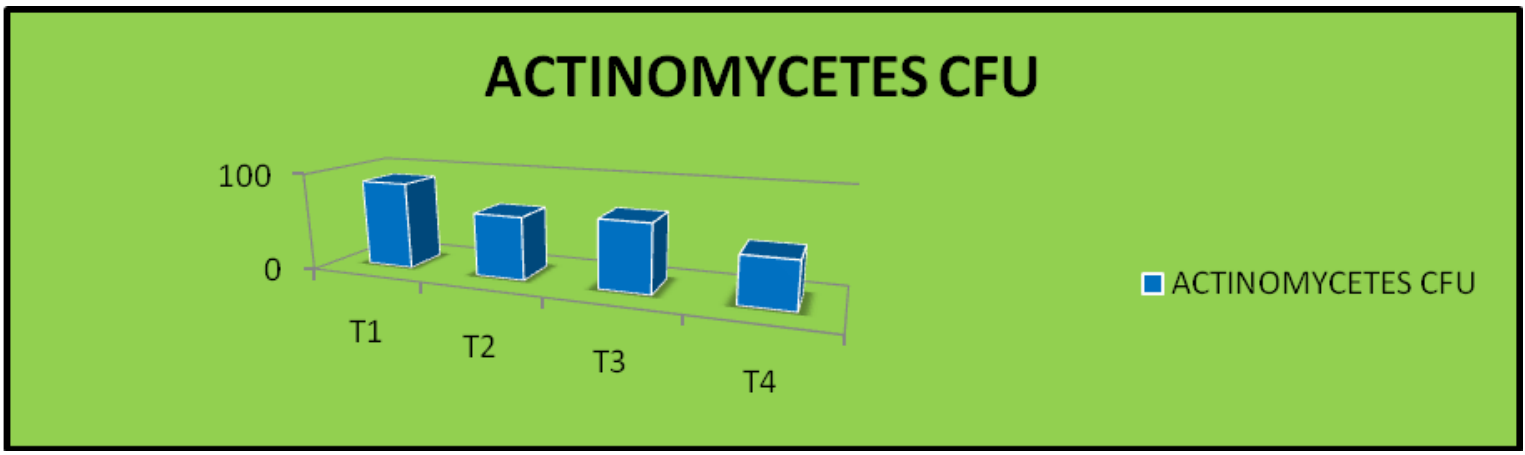

Fig.5 Counting of Bacteria population (cfuX10 $10^{5}$ per g).

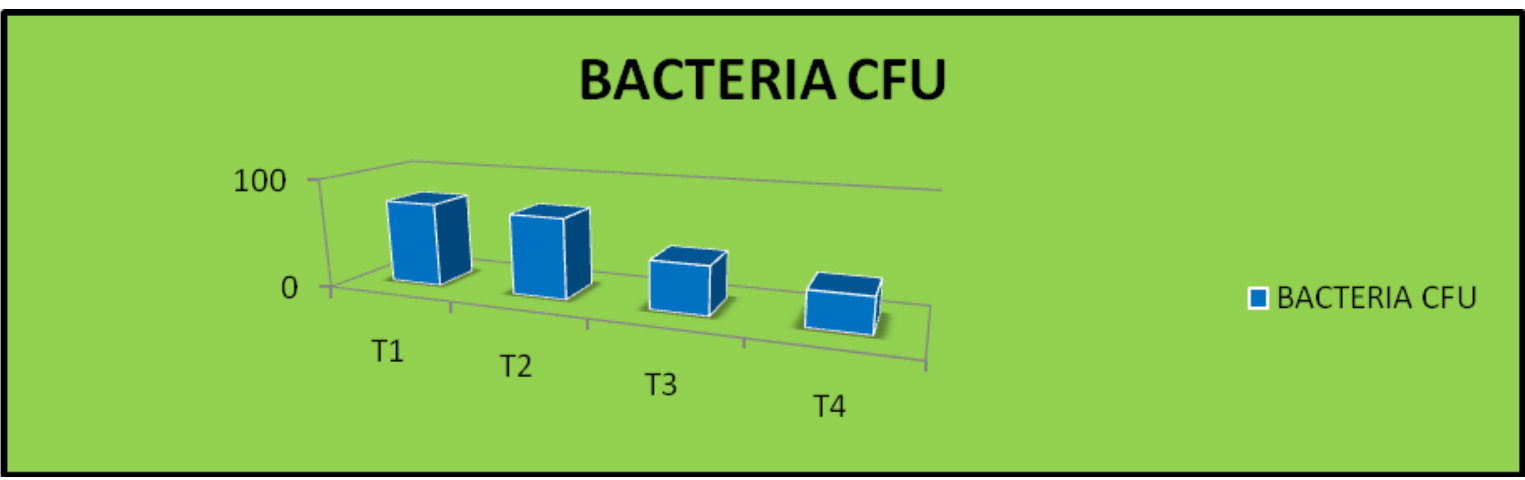

Fig.6 Intercropping marigold, tuberose and gerbera with coconut
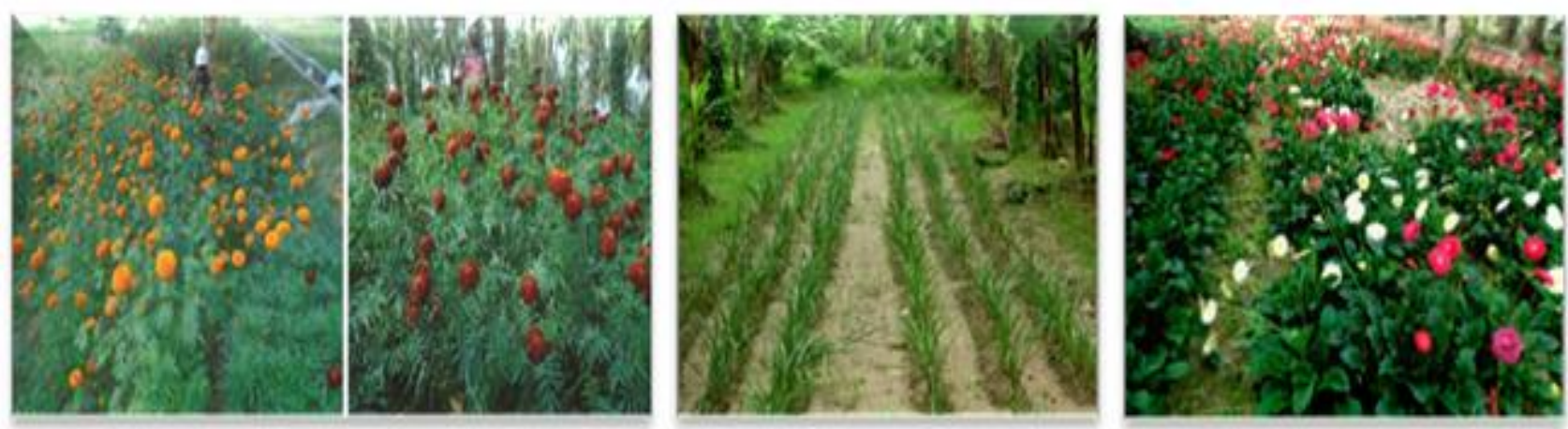
Fig.7 B:C ratio of coconut based cropping system.

\title{
B:C ratio of coconut based cropping system
}

\author{
1.75 \\ 1.7 \\ 1.65
}

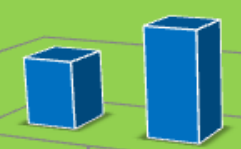

T1

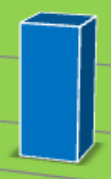

T3

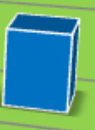

T4 $\square \mathrm{B}:$ C ratio of coconut based cropping system
In the present experiment, higher actinomycetes population was observed in intercropping of marigold treatment $(89 \mathrm{x}$ $\left.10^{5} \mathrm{cfu} / \mathrm{g}\right)$ followed by gerbera treatments $(6 \mathrm{x}$ $10^{5} \mathrm{cfu} / \mathrm{g}$ ) during flowering season. Lehmann et al., (2000) reported that the dynamic increase of the microorganisms in the rhizosphere of fruit crops intercropping with floricultural crops can be explained by the favourable quantitative and qualitative composition of organic compounds provided in the form of root exudates and crop residues. This fact was further confirmed by earlier workers from the previous investigations (Al Yahyai 2009, Abouziena 2010). Significantly higher microbial populations in intercropping treatments at all stages of observation might be due to healthy and conducive environment for the microorganisms as compared to the control plots (Sarathambal et al., 2015).

Data revealed from the present investigation recorded that the total actinomycetes population was significantly more in all the intercropping treatments. With progress of time, population was increased in all the treatments. The maximum bacteria population was found in intercropping of marigold treatment $\left(76 \times 10^{5} \mathrm{cfu} / \mathrm{g}\right)$ during flowering season followed by tuberose treatment $(72.5 \mathrm{x}$ $\left.10^{5} \mathrm{cfu} / \mathrm{g}\right)$ in coconut plantation during flowering period. This may be due to the fact that in intercropping conditions, more soil organic matter is available which provides nutrients to microorganisms resulting in their proliferation and later on, microorganisms take part in degradation process (Sarathambal et al., 2015).

Intercropping has significant effects on microbiological and chemical properties in the rhizosphere, which may contribute to the yield enhancement by intercropping. It also leads to significant changes in the populations of microorganisms and their activities thereby influencing the microbial ecological balance in the soil and affecting the productivity of soils. The microbes play vital role in soil fertility management, such as degradation of organic matter and soil nutrient transformations. Significant stimulation in soil microbial activity was observed under coconut based cropping system could be due to better soil physico-chemical environment and adequate amount of available nutrients. These findings are in full conformity with the findings of Bopaiah and Shetty (1991), Natarajan et al., (2010), Thomas and Prabhu (2003), Parab et al., (2015) in onion and Sarathambal et al., (2015) in mango. Soil microorganisms can act as agents of nutrient transformation and store carbon and nutrients in their own living biomass, acting as labile reservoirs for available nutrients with fast turnover (Mishra et al., 2011). The amount and activity of microorganisms therefore 
influence soil productivity and nutrient cycling. Increase in available $\mathrm{P}$ and $\mathrm{pH}$ in soil with organic manure perhaps accelerated the microbial activity of the soil, which in turn enhanced the available nutrient status of soil and consequently the crop yield.

\section{Future Scope of Research}

The present experiment indicated some interesting findings of immense practical utilisation on cropping pattern, soil type, microbial population in soil, nutrient management and production of intercrops and coconut. Microbial, production and nutrient parameters of four coconut based cropping system models have been studied.

But future researches aiming at relating to the microbes and nutrient up taking in soil of coconut based cropping system need to be undertaken as it was not possible to study these aspects during the present investigation.

However, immense scope is left for future research in this line mentioned below:

To study the enzymatic analysis, biomass production, organic carbon content of soil etc.

Studies on the relationship between microbial populations present in the soil of coconut based cropping system and nutrient up take by the crops (intercrop + coconut) need to be studied.

Micronutrient studies of coconut based cropping system can do in future.

The effect of soil microorganism's activities on benefit: cost ratio of coconut based cropping system can be analysed. Identification of beneficial and damaging microorganisms present in soil helping better growth, development and production of coconut and intercrops.
Other microbial population count can be done under coconut based cropping system like, $\mathrm{N}$ fixers, P- solubilizers, Trichoderma, Ganoderma population etc.

Microbial population counting may be recorded at different stages of plant growth (vegetative, flowering etc).

Influence of crop diversity and level of fertiliser inputs on microbial groups in the root zone of crops may be studied.

Microbial parameters like quantity of carbon, mineralised phosphatase and dehydrogenase activities of soil may be studied.

\section{Acknowledgement}

Authors thank to Prof. A. Bandyopadhyay Dept. Of Spices and Plantation Crops, Bidhan Chandra Krishi Viswavidyalaya, Mohanpur, Nadia, for his noble supervision, sagacious guidance, valuable suggestions, ever encouraging inspirations, humble behavior and tireless effort throughout the tenure of my investigation and also highly grateful to Prof. A. R. Mondal, Department of Vegetable Crops and Prof. A. Pariari, Department of Spices and Plantation Crops during my research work.

\section{References}

Bavappa, K. V. A, Kailasam, C, Khader, K. B. A, Biddappa, C. C, Khan, H. H, Kasturibai, K. V, Ramadasan, A, Sundararajan, P, Bopaiah, B. M, Thomas, V, George L. P., Misra, L. P, Balasainha, D, Bhat N. T. \& Bhat S. K. (1986). Coconut and arecanut based high density multispecies cropping system. $J$. Plantation crops, 14: 22, 74-87.

Bavappa, K. V. A. \& Jacob V. J. (1982). High intensity multispecies cropping - A new approach to small scale farming in the tropics. World crop, 2: 47-50.

Bopaiah B. M. and Shetty H. S. (1991). Microbiology and fertility in coconut-based mixed farming and coconut monocropping 
systems. Tropical-Agriculture. 68(2): 135138.

Bopaiah B. M. and Shetty H. S. (1991). Soil microflora and biological activities in the rhizospheres and root regions of coconutbased multistoreyed cropping and coconut monocropping systems. Soil-Biology-andBiochemistry. 23(1): 89-94.

Jackson, M. L. (1973). Soil Chemical Analysis. $2^{\text {nd }}$ Edition. Prentice Hall of India Pvt. Ltd., New Delhi, pp. 111-182.

Maheswarappa (2003) Economic significance and productivity of coconut based high density multi-species cropping system (HDMSCS) in root (wilt) affected area. Central Plantation Crops Research Institute, Regional Station, Kayamkulam - 690 533, Kerala, India. Indian-Coconut-Journal. 34(8): 3-5.

Maheswarappa, H. P, Anitakumari, P \& Sairam, C. V. (2003). High density multispecies cropping system for root (wilt) affected coconut gardens - Its impact on productivity and economic viability, J. Plantation crops, 31: 11, 23-27.

Mishra S., Sharma S., Vasudevan P., 2008. Comparative effect of biofertilizers on fodder production and quality in guinea grass (Panicum maximum Jacq.). J. Sci. Food Agric. 88 (9), 1667-1673.

Mishra S., Sharma S., Vasudevan P., 2009. Effect of single and dual inoculation of Rhizobium with AM fungi on nodulation, fodder production and quality in two Stylosanthes species. Biol. Agric. Hortic. 26, 411-421.
Natarajan C.; Subramanian P. S. and Mohandas S. (2010). Intercropping system in coconut for East Coast region of Tamil Nadu. Coconut Research Station, Tamil Nadu Agricultural University, Veppankulam - 614 906, India. Indian-Coconut-Journal. 53(3): 7-11.

Parab N, Sinha S and Mishra S (2015). Coal fly ash amendment in acidic field: Effect on soil microbial activity and onion yield. SIES Indian Institute of Environment Management, Sector-V, Nerul, Navi Mumbai 460 706, Maharashtra, India. Applied Soil Ecology. 96, 211-216.

Sarathambal C, Singh V. P., Barman K. K., Raghuvanshi M. S. and Dubey R. P. (2015). Intercropping and weed management effect on soil microbial activities in newly planted mango and citrus orchards. ICAR Directorate of Weed Research, Jabalpur Madhya Pradesh 482 004. Indian Journal of Weed Science 47(2): 178-182.

Thomas G. V. and Prabhu S. R. (2003). Association of diazotrophic and plant growth promoting rhizobacteria with coconut palm. Crop production division, central plantation crops research institute, Indian council of agricultural research, kasaragod 671124, kerala, india.

www.agritech.tnau.ac.in www.coconutboard.gov.in www.cpcri.gov.in www.icar.org.in www.mapsofindia.com www.perfectinsider.com https//books.google.co.in

\section{How to cite this article:}

Radhajogita Mondal, A. C. Das and Bandyapadhyay, A. 2021. Studies on Effect of Coconut based Cropping System on the Yield and Soil Microbial Activity. Int.J.Curr.Microbiol.App.Sci. 10(05): 217-229. doi: https://doi.org/10.20546/ijcmas.2021.1005.029 